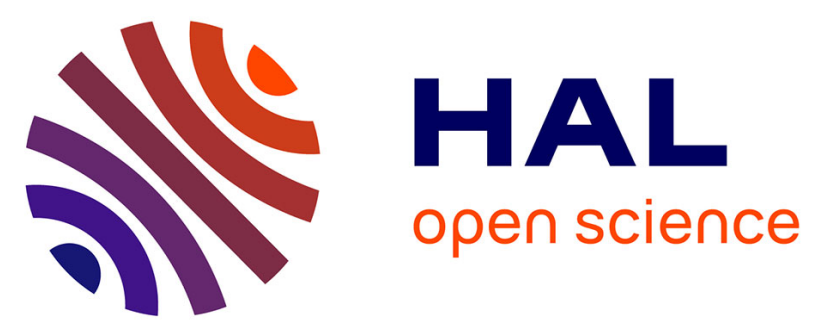

\title{
Oxygen reduction reaction catalyzed by overhanging carboxylic acid strapped iron porphyrins adsorbed on carbon nanotubes
}

Bernard Boitrel, Morgane Bouget, Pradip K Das, Stéphane Le Gac, Thierry

Roisnel, Manel Hanana, Hélène Arcostanzo, Renaud Cornut, Bruno

Jousselme, Stéphane Campidelli

\section{To cite this version:}

Bernard Boitrel, Morgane Bouget, Pradip K Das, Stéphane Le Gac, Thierry Roisnel, et al.. Oxygen reduction reaction catalyzed by overhanging carboxylic acid strapped iron porphyrins adsorbed on carbon nanotubes. Journal of Porphyrins and Phthalocyanines, 2020, 24 (05n07), pp.675-684. 10.1142/s1088424619501232 . cea-02302659

\section{HAL Id: cea-02302659 https://hal-cea.archives-ouvertes.fr/cea-02302659}

Submitted on 11 Dec 2020

HAL is a multi-disciplinary open access archive for the deposit and dissemination of scientific research documents, whether they are published or not. The documents may come from teaching and research institutions in France or abroad, or from public or private research centers.
L'archive ouverte pluridisciplinaire HAL, est destinée au dépôt et à la diffusion de documents scientifiques de niveau recherche, publiés ou non, émanant des établissements d'enseignement et de recherche français ou étrangers, des laboratoires publics ou privés. 


\title{
Oxygen Reduction Reaction Catalyzed by Overhanging Carboxylic Acid Strapped Iron Porphyrins Adsorbed on Carbon Nanotubes
}

\author{
Bernard Boitrel,,,a Morgane Bouget, ${ }^{a}$ Pradip K. Das, ${ }^{\text {a }}$ Stéphane Le Gac, ${ }^{\text {a }}$ Thierry \\ Roisnel, ${ }^{a}$ Manel Hanana, ${ }^{b}$ Hélène Arcostanzo, ${ }^{b}$ Renaud Cornut, ${ }^{b}$ Bruno Jousselme, ${ }^{b}$ \\ and Stéphane Campidelli ${ }^{*}, \mathrm{~b}$
}

${ }^{\text {a }}$ Univ Rennes, CNRS, ISCR (Institut des Sciences Chimiques de Rennes), UMR 6226, Rennes, F-35000, France.

${ }^{b}$ LICSEN, NIMBE, CEA, CNRS, Université Paris-Saclay, CEA Saclay 91191 Gif-sur-Yvette Cedex, France.

Received date (to be automatically inserted after your manuscript is submitted)

Accepted date (to be automatically inserted after your manuscript is accepted)

\begin{abstract}
A series of hybrid catalysts for the oxygen reduction reaction (ORR) has been investigated. They are composed of multi-wall carbon nanotubes (MWNTs) coated with iron strapped porphyrins. Two porphyrins have been probed; both are strapped with the same skeleton and differ only by the number of overhung carboxylic acid(s), either one or two. In this structure, the carboxylic acid group can act as a proton relay between the medium and the catalyst or as a polar group surrounding the dioxygen binding cavity. While the number of carboxylic acid group(s) does not exhibit a significant influence on the catalytic properties, the combination of both components - MWNTs and porphyrin - leads to a better catalytic activity than those of the nanotubes or the porphyrins taken separately.
\end{abstract}

KEYWORDS: Porphyrins / dioxygen reduction / Synthesis / X-ray diffraction / Catalysis

*Correspondence to: Fax: (33)2 2323 5637; Tel: (33)2 2323 5856; E-mail: Bernard.Boitrel@univ-rennes1.fr, stephane.campidelli@cea.fr 


\section{INTRODUCTION}

Oxygen Reduction Reaction (ORR) is the paramount reaction taking place at the cathode of a fuel cell. In aerobic life on Earth, Cytochrome $c$ Oxidase, the oxygen electrode of Nature's fuel cell is a famous example of protein performing the reduction of oxygen through the four-electron four-proton mechanism [1]. Thus, a plethora of catalysts based on iron "porphyrinoid" derivatives, mimicking the structure of the active center of the protein have been developed and extensively investigated for ORR $[2,3,4]$. However, where in nature a bimetallic center is required particularly under rate-limiting electron flux [5], it has been shown that "iron-only" tris(2-aminoethyl)amine (tren)-capped porphyrins, that is without any copper in the cap, could be efficient catalysts of the 4-electron reduction of dioxygen as long as electron supply is not a limiting factor as at the surface of an electrode [6]. This surprising result was then shown true for strapped or quinolinoyl picket porphyrins [7,8,9]. Finally, by grafting a carboxylic acid group around the binding site of the macrocycle, the hangman catalyst family was also found to be effective monometallic catalysts for the ORR [10,11]. This effectiveness was rationalized by the possible role of the carboxylic acid group as a proton-relay. The same concept has been extended to the study of meso-tetra-arylporphyrins with four carboxylic acid groups either in ortho or para position of the meso aromatic cycles. In the case of the ortho substitution, the selectivity was high for the four-electron process with a production of hydrogen peroxide quasi inexistent [12].

One of us, in previous work [13], has reported that the ORR activity of several non functionalized Co and Fe phthalocyanines and porphyrins immobilized by $\pi$-stacking interactions on various types of carbon nanotubes such as SWNTs, DWNTs, oxidized and non-oxidized MWNTs, was improved by the presence of the carbon nanotubes. However, as discussed by Rigsby et al. the nature and structure of the adsorbed catalyst are crucial parameters as well [14]. Thus, the formulation itself of a catalyst ink containing the same iron porphyrin, that is either deposited directly on glassy carbon (GC) or mixed with Vulcan and then deposited on GC electrode, has an effect at least as important as changing the structure of the molecular catalyst itself. In the same line, and more recently, we have reported on the synergistic effect on ORR of strapped porphyrins polymerized around carbon nanotubes [15]. It was shown that the presence of a potential proton relay in the hybrids materials in comparison with those lacking such a group did not generate any significant improvement. However, it is worth to mention that the spatial arrangement of the molecular catalyst, namely the iron porphyrin, properly functionalized with peripheral groups for the polymerization was expected to be somehow controlled by the covalent linkages between the porphyrin units.

Thus, in the present work, we now report on the ORR activity of MWNTs functionalized only by physisorption with specific iron (III) strapped porphyrins in a $\mathrm{pH}$ range from 13 to 6 . These porphyrins contain a bridge bearing one or two carboxylic functions between the phenyl groups in 5 and 15 meso positions (Scheme 1). The overhanging bridge should prevent the aggregation of the porphyrins compared to the previous studies while preserving one side available for the interaction with the nanotubes by $\pi$-stacking. The goal of this study is first to measure the ORR properties of strapped porphyrins bearing either one or two polar overhanging carboxylic acid(s) and second to evaluate the influence of the communication between the nanotube and the catalytic centers as well as the effects of the non-aggregation of the porphyrins adsorbed on the nanotube as depicted in Figure 1. 

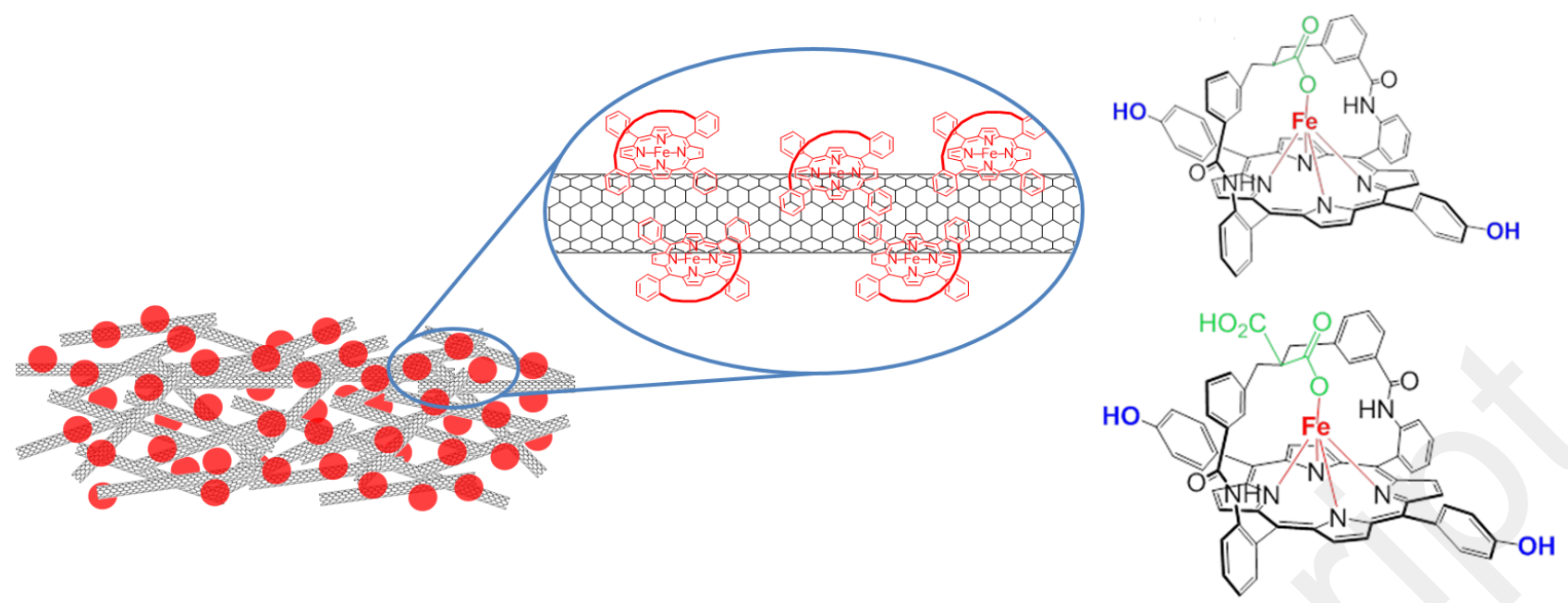

Figure 1. Schematic representation of the nanotube/porphyrins hybrids.

\section{RESULTS AND DISCUSSION}

Strapped-porphyrin derivatives $\mathbf{1 F e}$ and $\mathbf{2 F e}$ bearing one and two carboxylic acid functions respectively were prepared according to a synthetic pathway previously reported in the case of a single strap porphyrin bearing 3,5dihydroxyphenyl in the 10,20 meso positions [16]. Chiefly, the synthesis of $\mathbf{2}$, summarized in Scheme 1, began by condensation of 5-(4-methoxyaryl)dipyrrylmethane 3 with 2-nitrobenzaldehyde in acidic conditions to obtain porphyrin 4 whose nitro groups were reduced by tin chloride in acidic medium leading to a mixture of the two atropisomers of the resulting aminophenyl porphyrin. Then, the atropisomer $\alpha \alpha \mathbf{5}$ was separated by silica gel flash chromatography and acylated with 3-chloromethyl benzoyl chloride in the presence of triethylamine to obtain porphyrin $\mathbf{6}$. Condensation of diethyl malonate in basic conditions allowed the formation of the strap in the 5,15 meso positions of the resulting porphyrin 7 and finally treatment by $\mathrm{BBr}_{3}$ of the latter supplied free base porphyrin $\mathbf{2}$. Actually, both porphyrins $\mathbf{1 F e}$ and $\mathbf{2 F e}$ were obtained by refluxing free-base porphyrin $\mathbf{2}$ in THF in the presence of iron(II) bromide and 2,6-lutidine in a glove box. During this process, the decarboxylation reaction leading partially to $\mathbf{1 F e}$ was observed and the two complexes were obtained in roughly equal proportions as indicated by TLC analysis and were separated by silica gel chromatography out of the glovebox after oxidation and identified by MALDI-TOF mass spectrometry (see experimental part).

Among the two final iron porphyrins, we were able to obtain single crystals of $\mathbf{1 F e}$ and to solve its X-ray structure (Figure 2 and Table 1). The latter indicates that the iron cation is square-pyramidal five-coordinate with the intramolecular carboxylate bound on it with a Fe-O1 bond lenght of $1.997 \AA$. This intramolecular binding implies a significant distortion of the strap wich retains a "W-shape" as observed on the apical view (Figure 2, right). Although a similar coordination polyhedron has already been reported for the bis-carboxylato analogous complex of $\mathbf{1 F e}$ [15], in the present case, the strap is more distorted with the carbon atom C2 diving toward the macrocycle plane (3.935 ̊ from iron against $4.301 \AA$ for the non-decarboxylated complex) and with a distance of the iron atom to the mean porphyrin plane of $0.449 \AA$, against $0.512 \AA$ for the non-decarboxylated complex. The very same distorted conformation was also found in an analogous zinc complex in which the distance of the metal to the mean porphyrin plane was only $0.386 \AA$ [17], clearly indicating that this type of strap remains quite flexible. The macrocycle is strongly saddle-shaped with almost no ruffling, as indicated by the angle with the mean plane of the two pairs of diametrically opposed pyrrole rings (N1 and N3: $-13.02^{\circ}$ and $-12.68^{\circ}$; N2 and N4: $11.14^{\circ}$ and 14.06 ). 


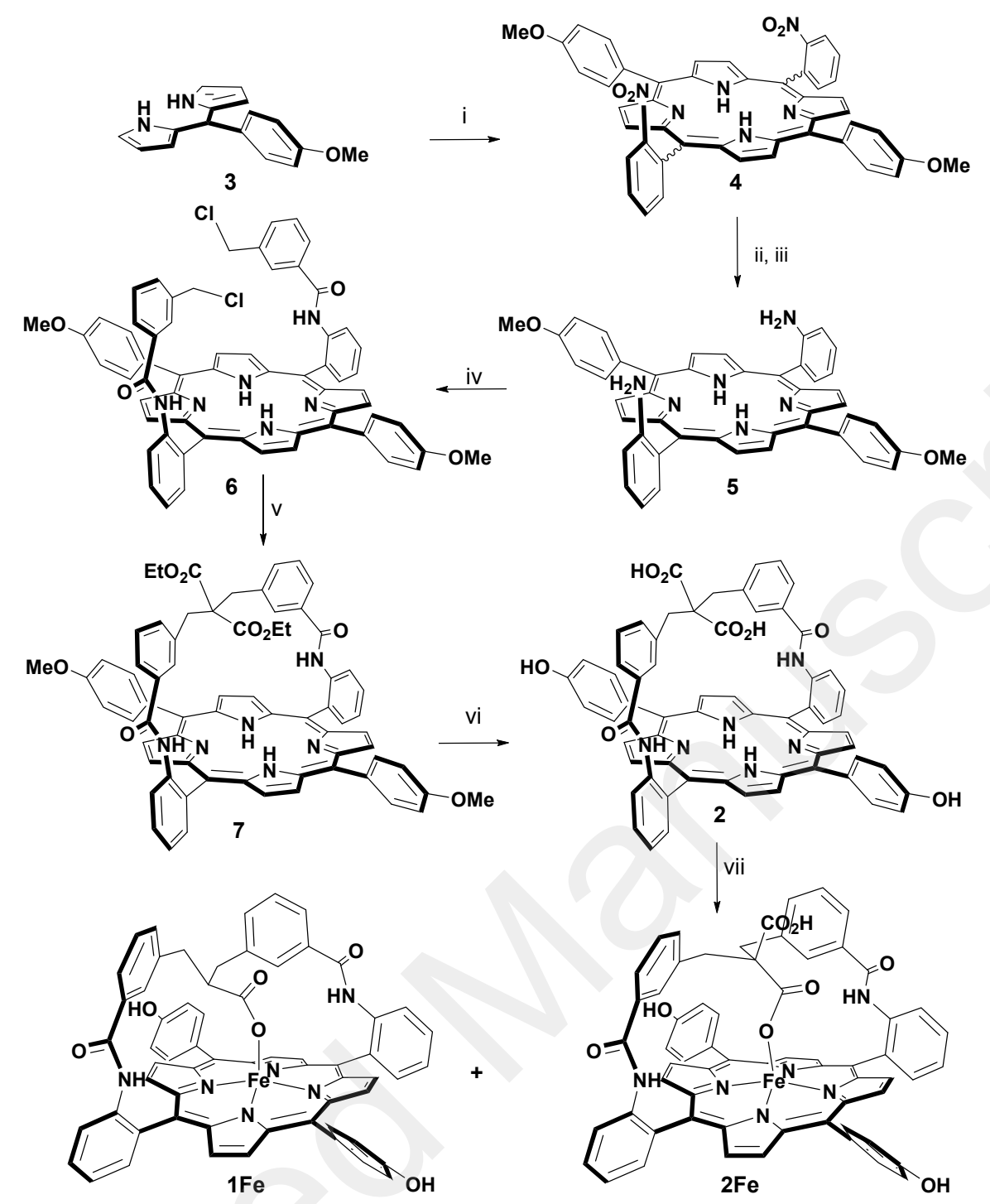

Scheme 1. Synthesis of iron porphyrins $1 \mathrm{Fe}$ and $2 \mathrm{Fe}$ bearing one and two overhanging carboxylic acid groups respectively, for MWNT coating. (i) 2-nitrobenzaldehyde, $\mathrm{CH}_{2} \mathrm{Cl}_{2}, \mathrm{BF}_{3}-\mathrm{Et}_{2} \mathrm{O}, 2 \mathrm{~h}$, then $\mathrm{DDQ}, 20 \%$; (ii) $\mathrm{SnCl}_{2}, \mathrm{HCl}, 80 \%$; (iii) silica gel chromatography, $\mathrm{CH}_{2} \mathrm{Cl}_{2}, 66 \%$; (iv) 3-(chloromethyl)benzoyl chloride (3 eq), $\mathrm{NEt}_{3}, \mathrm{THF}, 85 \%$; (v) $\mathrm{CH}_{2}\left(\mathrm{CO}_{2} \mathrm{Et}\right)_{2}$ (10 equiv.), THF, EtONa, room temp., 12 h, 80\%; (vi) $\mathrm{BBr}_{3}, \mathrm{CH}_{2} \mathrm{Cl}_{2}$, room temp., 12 h, 80\%; (vii) $\mathrm{FeBr}_{2}$, 2,6-lutidine, THF, reflux overnight, silica gel column chromatography after air oxidation and $\mathrm{HCl}(1 \mathrm{M})$ washing, $\mathbf{1 F e}(41 \%), \mathbf{2 F e}(37 \%)$.
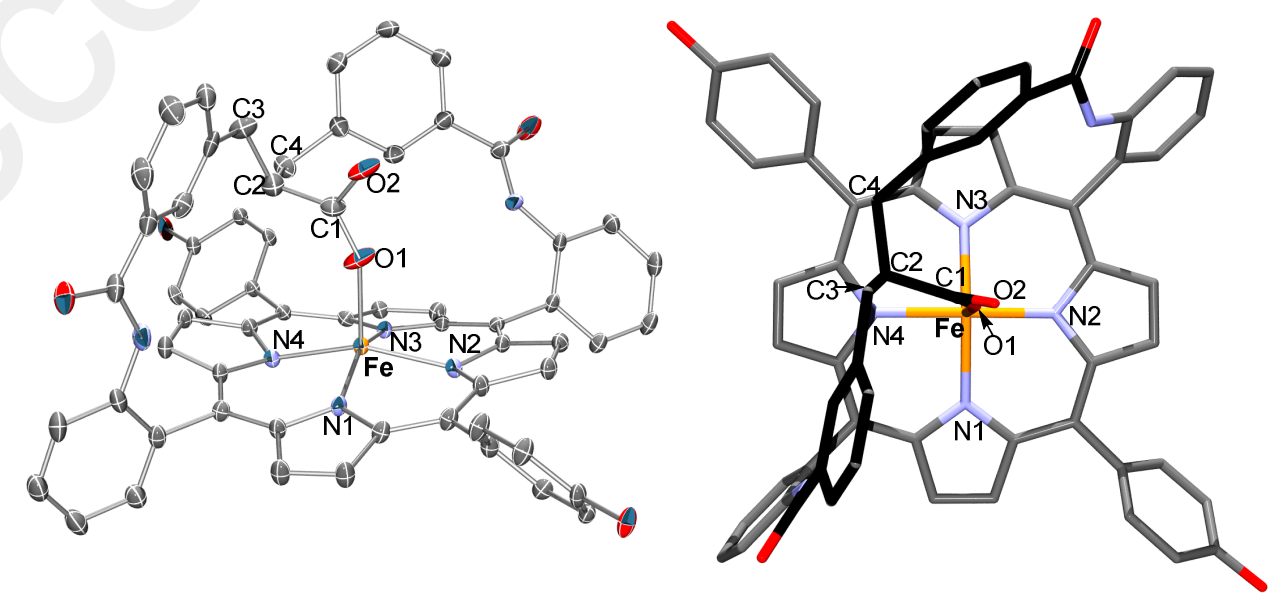
Figure 2. X-ray structure of 1Fe. Top: ORTEP lateral view (30\% thermal ellipsoids) and bottom: apical rods view with the carbon atoms of the strap colored in black. Selected distances (Å): N1-Fe 2.066, N2-Fe 2.049, N3-Fe 2.061, N4-Fe 2.056, O1-Fe 1.997, C1O1 1.232, C1-O2 1.230, (Fe, 24MP) 0.449

\begin{tabular}{|c|c|}
\hline Empirical formula & $\mathrm{C}_{62} \mathrm{H}_{41} \mathrm{Fe} \mathrm{N}_{6} \mathrm{O}_{6}$ \\
\hline Formula weight & $1021.86 \mathrm{~g} / \mathrm{mol}$ \\
\hline Temperature & $150(2) K$ \\
\hline Wavelength & $0.71073 \AA$ \\
\hline Crystal system, space group & triclinic, $P-1$ \\
\hline \multirow[t]{3}{*}{ Unit cell dimensions } & $a=14.499(2) \AA, \alpha=90.838(5)^{\circ}$ \\
\hline & $b=14.729(2) \AA, \beta=109.567(6)^{\circ}$ \\
\hline & $c=17.848(3) \AA, \gamma=117.362(5)$ \\
\hline Volume & $3124.0(8) \AA^{3}$ \\
\hline$Z$, Calculated density & $2,1.086 \mathrm{~g} . \mathrm{cm}^{-3}$ \\
\hline Absorption coefficient & $0.291 \mathrm{~mm}^{-1}$ \\
\hline$F(000)$ & 1058 \\
\hline Crystal size & $0.320 \times 0.260 \times 0.110 \mathrm{~mm}$ \\
\hline Crystal color & black \\
\hline Theta range for data collection & 3.026 to $27.484^{\circ}$ \\
\hline h_min, h_max & $-18,18$ \\
\hline k_min, k_max & $-19,19$ \\
\hline 1_min, 1_max & $-23,23$ \\
\hline Reflections collected / unique & $57073 / 13966\left[R(\text { int })^{\mathrm{a}}=0.1159\right]$ \\
\hline Reflections $[I>2 \sigma]$ & 9825 \\
\hline Completeness to theta_max & 0.975 \\
\hline Absorption correction type & multi-scan \\
\hline Max. and min. transmission & $0.968,0.776$ \\
\hline Refinement method & Full-matrix least-squares on $F^{2}$ \\
\hline Data / restraints / parameters & 13966 / 0 / 672 \\
\hline${ }^{\mathrm{b}} S$ (Goodness-of-fit) & 1.036 \\
\hline Final $R$ indices $[\mathrm{I}>2 \sigma]$ & $R 1^{c}=0.0888, w R 2^{d}=0.2340$ \\
\hline$R$ indices (all data) & $R 1^{c}=0.1213, w R 2^{d}=0.2579$ \\
\hline Largest diff. peak and hole & 1.852 and $-1.601 \mathrm{e}^{-} . \AA^{-3}$ \\
\hline \multicolumn{2}{|l|}{${ }^{a} R_{i n t}=\sum\left|\mathrm{F}_{\mathrm{o}}^{2}-\left\langle\mathrm{F}_{\mathrm{o}}^{2}\right\rangle\right| / \sum\left[\mathrm{F}_{\mathrm{o}}^{2}\right]$} \\
\hline \multicolumn{2}{|c|}{${ }^{b} S=\left\{\sum\left[w\left(\mathrm{~F}_{\mathrm{o}}^{2}-\mathrm{F}_{\mathrm{c}}^{2}\right)^{2}\right] /(n-p)\right\}^{1 / 2}$} \\
\hline \multicolumn{2}{|l|}{${ }^{c} R 1=\sum|| F_{o}|-| F_{c}|| / \sum\left|F_{o}\right|$} \\
\hline \multicolumn{2}{|c|}{${ }^{d} w R 2=\left\{\sum\left[w\left(F_{o}^{2}-F_{c}^{2}\right)^{2}\right] / \sum\left[w\left(F_{o}^{2}\right)^{2}\right]\right\}^{1 / 2}$} \\
\hline$w=1 /\left[\sigma\left(F_{\mathrm{o}}^{2}\right)+\mathrm{a} P^{2}+\mathrm{b} P\right]$ whe & $P=\left[2 F_{\mathrm{c}}{ }^{2}+\operatorname{MAX}\left(F_{\mathrm{o}}{ }^{2}, 0\right)\right] / 3$ \\
\hline
\end{tabular}

Table 1. X-ray structural data of 1Fe. 
In order to prepare the hybrid materials, MWNT (Nanocyl NC3100 ${ }^{\mathrm{TM}}$ ) were purified by treatment with nitric acid (35\%) at $100^{\circ} \mathrm{C}$ for $5 \mathrm{~h}$ (see experimental section). After treatment the nanotubes were diluted with iced-water, filtered through $0.45 \mu \mathrm{m}$ PTFE membrane and extensively washed with water and then with methanol. The catalysts were prepared by mixing MWNT with porphyrins $\mathbf{1 F e}$ or $\mathbf{2 F e}$ (in a 1:1 ratio in weight) in THF under bath sonication. After mixing, THF was evaporated and the catalyst inks were prepared by dispersing, using bath sonication, the different MWNT/porphyrin hybrids $(3 \mathrm{mg})$ in $750 \mu \mathrm{L}$ of ethanol and $75 \mu \mathrm{L}$ of Nafion solution (5\% in alcohol). Similarly, the inks of the reference compounds MWNT, 1Fe and 2Fe were prepared by mixing the nanotubes or the porphyrins in $750 \mu \mathrm{L}$ of ethanol and $75 \mu \mathrm{L}$ of Nafion solution (5\% in alcohol). The catalysts were drop-casted on the Glassy Carbon disk and tested in a series of Rotating Ring Disk Electrode experiments at pH 13 (NaOH, 0.1M), pH 10, 8 and 6 (phosphate buffers).

We first compared the electrocatalytic properties of the different components: MWNT, iron porphyrins 1 Fe and 2Fe and the 1:1 mixture MWNT-1Fe and MWNT-2Fe at pH 13 (Figure 3) and pH 10 (Figure 4). All the curves correspond to the average (reduction and reoxidation) of the cyclic voltammetry curves.

Figure 3a-b present the comparison between the ORR activity of MWNT-1Fe, MWNT-2Fe and those of the iron porphyrins deposited directly on the Glassy Carbon (GC) electrode. The curves show that the catalyst inks made by mixing the nanotubes with the porphyrins exhibit higher current density and lower overpotential (of about $0.1 \mathrm{~V}$ ) than porphyrins alone. This result is not surprising since similar observations were made by Rigsby et al. in the case of iron porphyrins deposited on different carbon supports [14]. In addition, it is interesting to notice that the voltammetry curves of MWNT-1Fe and MWNT-2Fe exhibit two waves at around -0.4 and -0.7 V, explained by the own activity of the nanotubes (see below). Figure 3c shows the activity of MWNT and Figure $3 \mathrm{~d}$ compares the voltammetry curves (0 and $2000 \mathrm{rpm}$ ) of MWNT, 1Fe and MWNT-1Fe. First, we observe that, at pH 13, MWNT reduced oxygen with lower overpotential and higher current density than 1 Fe. Second, the reduction starts roughly at the same potential $(-0.2 \mathrm{~V}$ vs $\mathrm{Ag} / \mathrm{AgCl}$ ) for MWNT and MWNT-1Fe. Multi-walled carbon nanotubes are active materials for oxygen reduction in alkaline media [18,19] and it is likely that the nanotubes are more competitive than the nanotube/porphyrin hybrids at pH 13. It can explain the two waves observed on the reduction curves of the nanotube/porphyrin hybrids. We believe that the reduction initiated on the nanotubes is then performed by the porphyrin at lower potential. Nevertheless, when the plateau is reached at $-0.8 \mathrm{~V}$ vs $\mathrm{Ag} / \mathrm{AgCl}$ the current density is larger of ca. $2 \mathrm{~mA} / \mathrm{cm} 2$ for MWNT-1Fe compared to MWNT alone.

Figure 4 shows the same comparison between the ORR activity of MWNT, MWNT-1Fe, MWNT-2Fe and those of 1Fe and 2Fe deposited on the GC electrode, but at $\mathrm{pH}=10$. Once again, the curves clearly demonstrate that the catalyst inks made by mixing the nanotubes with the porphyrins exhibit higher current density than porphyrins alone. The reduction of oxygen starts with an overpotential of almost $0.4 \mathrm{~V}$ for $\mathbf{1 F e}$ and $\mathbf{2 F e}$ compared to the same porphyrin deposited on the nanotubes. MWNT-1Fe and MWNT-2Fe exhibit very similar properties, it appears that the presence of one or two carboxylate functions does not influence the properties under alkaline conditions. At pH 10, MWNT become less competitive for oxygen reduction than MWNT-1Fe or MWNT-2Fe and only one reduction wave is observed.

The comparison of the ORR activity (RDE and RRDE) of MWNT, 1Fe, 2Fe, MWNT-1Fe and MWNT-2Fe for pH 8 and pH 6 are given in Figure S1 and Figure S2, respectively. The catalytic activities of MWNT-1Fe and MWNT-2Fe (and of the reference compounds) exhibit the same trend with respect to those observed at $\mathrm{pH} 13$ and 10 . We also performed tests at $\mathrm{pH} 6$ and $\mathrm{pH} 8$ with porphyrin that does not exhibit proton relay and similar results to those obtained for MWNT-1Fe were obtained [15]. The presence of the proton in close proximity to the iron center does not seem to be mandatory to improve the reaction in our case. Indeed the presence of Nafion in the mixture probably ensures the availability of proton close to the reaction center. 

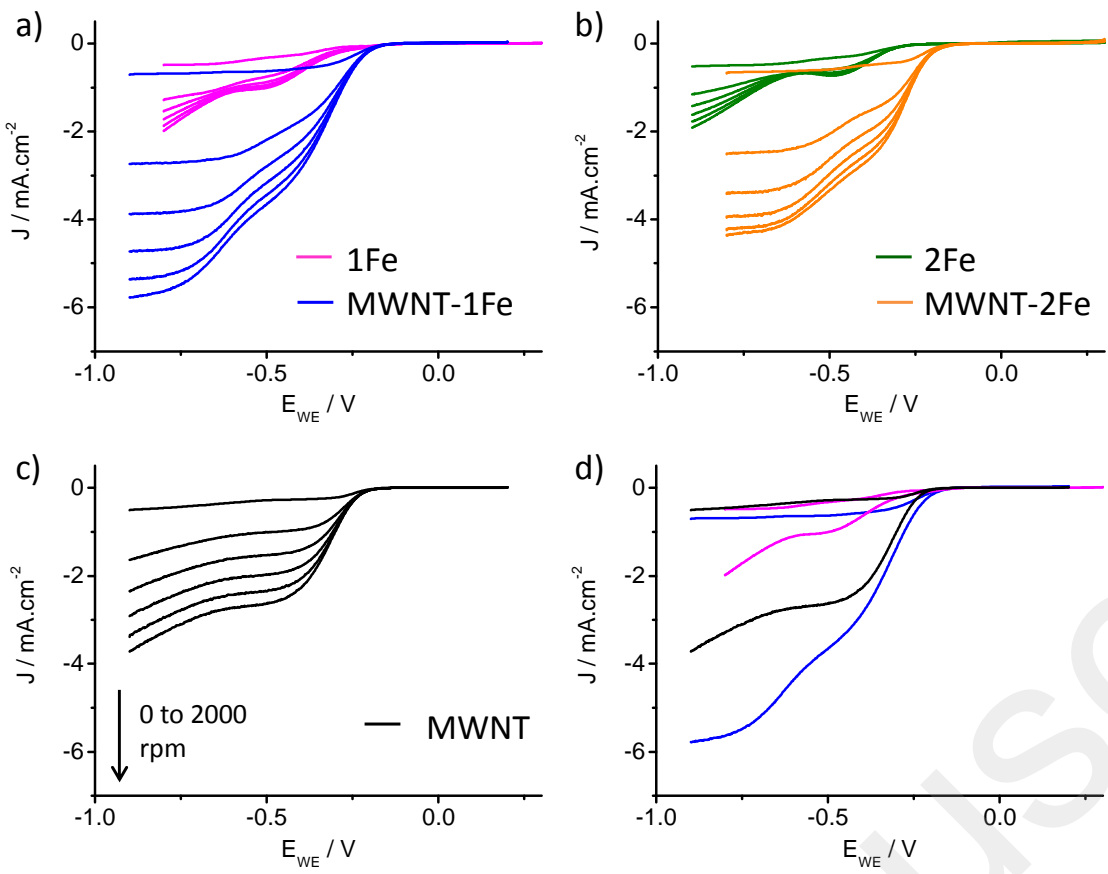

Figure 3. Polarization curves at different rotation rates $(0,400,800,1200,1600$ and $2000 \mathrm{rpm})$ recorded for ORR in $\mathrm{O}_{2}$-saturated $0.1 \mathrm{M} \mathrm{NaOH}$ solution ( $\mathrm{pH}$ 13) (scan rate $=5 \mathrm{mV} / \mathrm{s}$, room temperature) on GC with predeposited (a) 1Fe (pink) and MWNT-1Fe (blue); (b) 2Fe (green) and (c) MWNT-2Fe (orange); MWNT (black). (d) Comparison between MWNT, MWNT-1Fe and 1Fe at 0 and $2000 \mathrm{rpm}$.
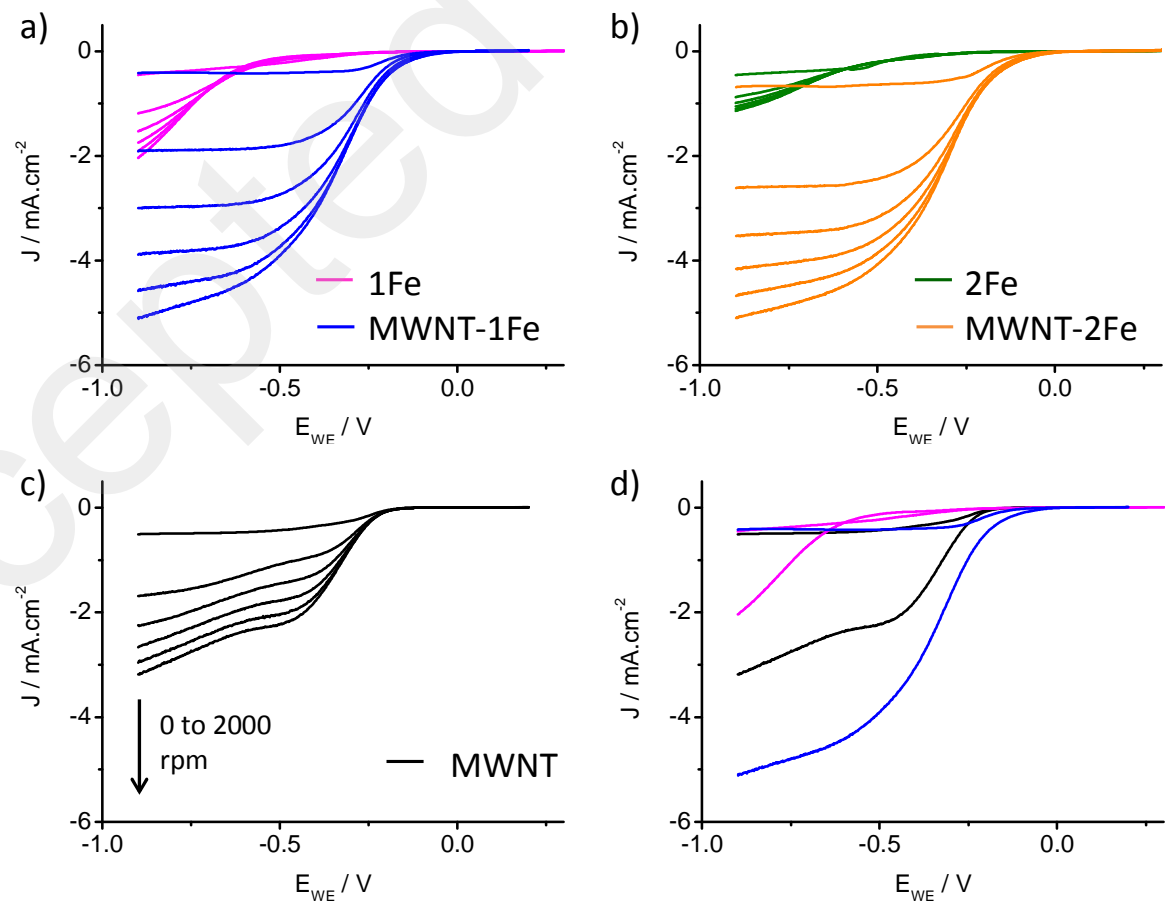

Figure 4. Polarization curves at different rotation rates $(0,400,800,1200,1600$ and $2000 \mathrm{rpm})$ recorded for $\mathrm{ORR}_{\text {in }} \mathrm{O}_{2}$-saturated at pH 10 (phosphate buffer solution) (scan rate $=5 \mathrm{mV} / \mathrm{s}$, room temperature) on GC with predeposited (a)1Fe (pink) and MWNT-1Fe (blue); (b) 2Fe (green) and MWNT-2Fe (orange); (c) MWNT (black). (d) Comparison between MWNT, MWNT-1Fe and 1Fe at 0 and $2000 \mathrm{rpm}$. 
It is worth mentioning that at $\mathrm{pH} 6$ and lower, the ORR activity of the porphyrins decreases rapidly and almost completely vanishes after the 3 cycles requiring the deposition of a new catalyst ink for each rotation cycle. This loss of ORR activity can be due to demetalation of the porphyrin during the electrochemical processes [20,21], this effect being well documented in the case of iron phthalocyanine $[22,23,24]$ but still subject to debate in the case of porphyrins.

Figure 5 shows the RRDE curves registered at a rotation rate of $400 \mathrm{rpm}$ for MWNT, MWNT-1Fe and 1Fe at pH 13 and 10. The numbers of electrons $n$ involved in the reduction, summarized in Table 2 were determined following the equation $n=4 I_{\mathrm{d}} /\left(I_{\mathrm{d}}+I_{\mathrm{r}} / N_{\mathrm{c}}\right)$ as recommended by Qiao et al.[25], from the disk and ring currents and with a collection coefficient $N_{\mathrm{c}}=0.2$ determined using the one-electron $\mathrm{Fe}(\mathrm{CN})_{6}{ }^{3-} / \mathrm{Fe}(\mathrm{CN})_{6}{ }^{4-}$ redox couple. From the curves, it is observed that the reduction of $\mathrm{O}_{2}$ is accompanied by the production of hydrogen peroxide both for MWNT and 1Fe. Conversely, for MWNT-1Fe, almost no production of $\mathrm{H}_{2} \mathrm{O}_{2}$ is detected at the plateau. At pH 13 a bump in the ring current between -0.20 and $-0.70 \mathrm{~V}$ reflecting the production of $\mathrm{H}_{2} \mathrm{O}_{2}$ is observed; however, this phenomenon is attributed to the initial reduction of oxygen by the nanotubes and appears before the plateau at disk is reached. However, at both $\mathrm{pH}$, the evaluated value of $\mathrm{n}$ remains close to the ideal value of 4 .
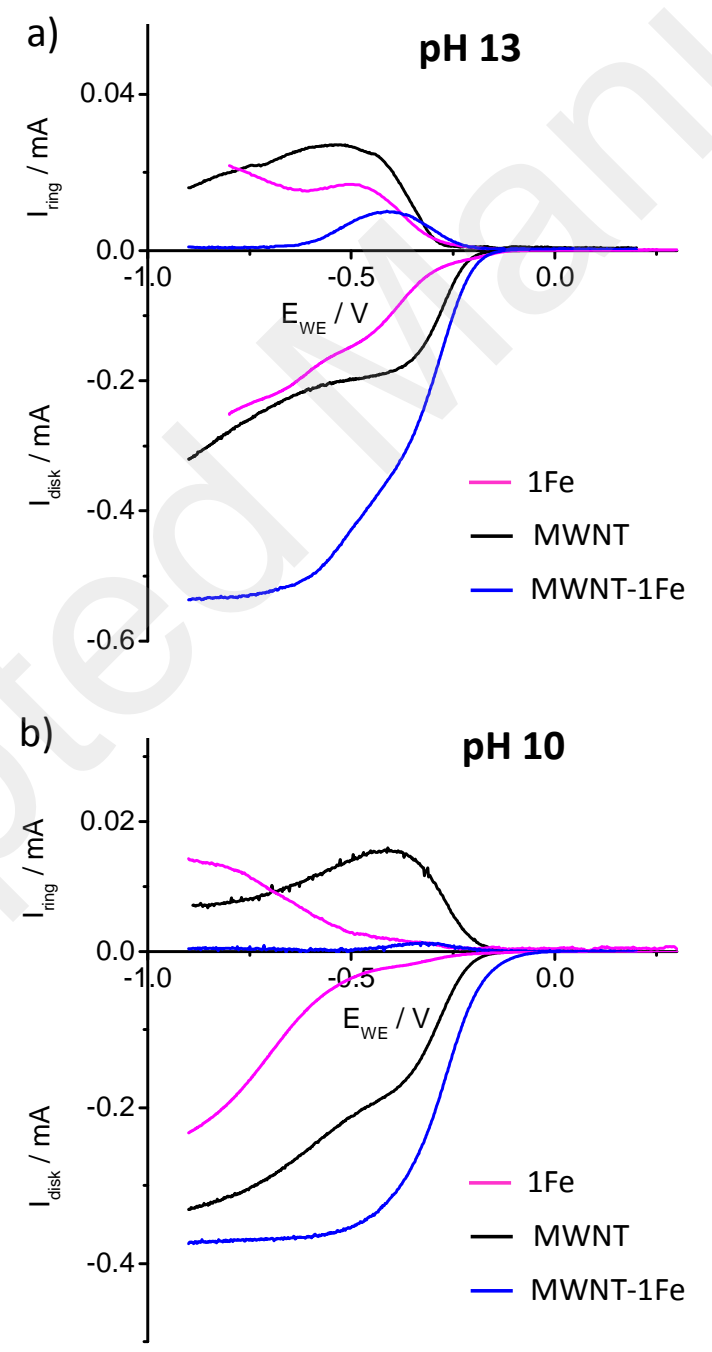

Figure 5. RRDE measurements of oxygen reduction (negative current) and hydrogen peroxide oxidation (positive current) for MWNT (black), 1Fe (pink) and MWNT-1Fe (blue) at (a) $\mathrm{pH} 13$ and (b) $\mathrm{pH} 10$ in $\mathrm{O}_{2}$-saturated solutions. The ring electrode was polarized at $0.260 \mathrm{~V} v s \mathrm{Ag} / \mathrm{AgCl}$. Rotation rate: $400 \mathrm{rpm}$; scan rate: $5 \mathrm{mV} \mathrm{s}^{-1}$. 


\begin{tabular}{cccc}
$\mathrm{pH} 10$ & 3.22 & 3.54 & 3.98 \\
& & & \\
\hline $\mathrm{pH} 13$ & 2.81 & 2.82 & 3.97
\end{tabular}

${ }^{a}$ potential chosen on the plateau for MWNT-1Fe.

Table 2. Number of electrons involved in the reduction of $\mathrm{O}_{2}$ at $-0.75 \mathrm{~V}^{a} v s \mathrm{Ag} / \mathrm{AgCl}$

\section{CONCLUSION}

Herein we formulated a series of catalyst inks for oxygen reduction reaction containing strapped porphyrins and MWNTs. The combination of the nanotubes with the iron porphyrins systematically gives better catalytic properties than those of two components taken separately. While carbon nanotubes are known to be slightly active in oxygen reduction, they produce significant amounts of hydrogen peroxide. When porphyrins are simply mixed in Nafion and deposited on the glassy carbon electrode, a low efficiency is generally observed. We attribute this behavior to the lack of electrons available for the reduction. Indeed in the catalyst ink, the porphyrins are embedded in Nafion and only the porphyrins close to the glassy carbon disk can benefit from efficient electron transfers from the electrodes. Conversely, carbon nanotubes create a percolating pathway for the charges in the catalyst film that ensure electron availabilities for the reduction of oxygen. In this case almost no hydrogen peroxide is produced and the reduction of oxygen is mostly performed via a 4 electrons pathway. However, under acidic conditions, at $\mathrm{pH} 6$ and lower, the catalytic activity of these inks decreased rapidly.

\section{EXPERIMENTAL}

\section{Materials and methods}

Mass spectra: ESI: Micromass MS/ MS ZABSpec TOFF spectrometer MALDI-TOF: Microflex-LT Bruker Daltonics were performed at the C.R.M.P.O. (University of Rennes 1 ). ${ }^{1} \mathrm{H}$ - and ${ }^{13} \mathrm{C}-\mathrm{NMR}$ spectra were recorded either on BrukerAvance 500 or BrukerAvance400 spectrometers equipped with a BBFO probe. Spectra were referenced with residual solvent protons. UV/ Vis spectra were recorded on an Uvikon XL spectrometer. Chemicals were purchased from Aldrich and were used as received. Solvents were purchased form Aldrich or VWR and were used as received. THF (K/benzophenone, $\mathrm{N}_{2}$ ) was distilled before use. MWNT commercial grade NC3100 (>95\%) were purchased from Nanocyl.

Synthesis. Porphyrin ligands. (4-methoxyphenyl)-dipyrromethane 3. In a two neck round bottom flask equipped with a stir bar and a gas inlet, 4-methoxy benzaldehyde $(92.8 \mathrm{mmol}, 11.3 \mathrm{~mL})$ and pyrrole $(161.2 \mathrm{~mL}, 25$ equiv.) were mixed. The reaction mixture was degassed for 15 minutes in argon under dark at room temperature, and then TFA (707 $\mu \mathrm{L}, 0.1$ equiv.) was added. The solution was stirred for further half an hour. The reaction was monitored by TLC, after that the reaction mixture was quenched by $\mathrm{Et}_{3} \mathrm{~N}$. The excess pyrrole was recovered under reduced pressure. The 
resulting solid was dissolved in $\mathrm{CH}_{2} \mathrm{Cl}_{2}$ and directly loaded on a silica gel chromatography column. The desired compound eluted with $70 \% \mathrm{CH}_{2} \mathrm{Cl}_{2}$-cyclohexane was obtained in 50\% yield $(11.65 \mathrm{~g}, 46.17 \mathrm{mmol})$. ${ }^{1} \mathrm{H} \mathrm{NMR}\left(\mathrm{CDCl}_{3}\right.$, $298 \mathrm{~K}, 500.13 \mathrm{MHz}): \delta 7.90\left(2 \mathrm{H}, \mathrm{pyr}_{\mathrm{NH}}\right), 7.18\left(2 \mathrm{H}, \mathrm{d}, J=8.61 \mathrm{~Hz}, \operatorname{aro}_{2}\right), 6.91\left(2 \mathrm{H}, \mathrm{d}, J=8.61 \mathrm{~Hz}, \operatorname{aro}_{3}\right), 6.71(2 \mathrm{H}, \mathrm{m}$, $\left.\mathrm{pyr}_{4}\right), 6.22\left(2 \mathrm{H}, \mathrm{m}, \mathrm{pyr}_{3}\right), 5.97\left(2 \mathrm{H}, \mathrm{m}, \mathrm{pyr}_{2}\right), 5.44\left(1 \mathrm{H}, \mathrm{CH}_{\alpha}\right), 3.84(3 \mathrm{H}, \mathrm{s}, \mathrm{OMe}) .{ }^{13} \mathrm{C} \mathrm{NMR}\left(\mathrm{CDCl}_{3}, 298 \mathrm{~K}, 500.13\right.$ $\mathrm{MHz}): \delta 158.5,134.3,132.9,129.4,117.2,114,108.3,107.2,55.3,43.2$. ESI-HRMS: calcd m/z $=275.1154$ [M$\mathrm{H}+\mathrm{Na}]^{+}$for $\mathrm{C}_{16} \mathrm{H}_{16} \mathrm{~N}_{2} \mathrm{NaO}$, found 275.1159 .

5,15-bis-(2-nitrophenyl)-10,20-bis-(4-methoxyphenyl)-porphyrin 4. Samples of 4-methoxyphenyldipyrromethane 3 (7.9 mmol, $2 \mathrm{~g})$ and 2-nitrobenzaldhyde (1.19 g, 1 equiv.) were dissolved in freshly prepared distilled $\mathrm{CH}_{2} \mathrm{Cl}_{2}(600 \mathrm{~mL})$ in a $1 \mathrm{~L}$ round-bottomed flask containing molecular sieves, degassed with a stream of $\mathrm{Ar}$ for 15 min. $\mathrm{Then}^{\mathrm{BF}} \mathrm{Et}_{2} \mathrm{O}$ (110 $\mu \mathrm{L}, 0.1$ equiv.) was added slowly over $30 \mathrm{~s}$. The reaction was stirred at room temperature and monitored by TLC and MALDI. After 2 hours, DDQ (2.7 g, 1.5 equiv.) was added, and the reaction mixture was stirred at room temperature for a further $1 \mathrm{~h}$. The complete reaction mixture was quenched by $\mathrm{Et}_{3} \mathrm{~N}$ and evaporated under reduced pressure to give a black solid which was dissolved in $\mathrm{CH}_{2} \mathrm{Cl}_{2}$. The mixture of two atropisomers i.e. $\alpha \beta$ and $\alpha \alpha$-bis-2nitrophenylporphyrin were purified by silica gel column chromatography using $\mathrm{CH}_{2} \mathrm{Cl}_{2}$ as eluent. The atropisomers could not be separated by the usual method of column chromatography on silica gel due to the same polarity. Overall yield: $600 \mathrm{mg}(20 \%)$.

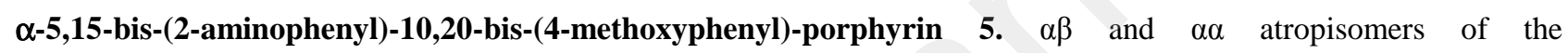
dinitroporphyrin 4 (5.2 mmol, $4 \mathrm{~g}$ ) were dissolved in the mixture of $\mathrm{CH}_{2} \mathrm{Cl}_{2}-\mathrm{MeOH}(100 \mathrm{~mL})$, taken in a $2 \mathrm{~L}$ conical flask along with a reducing agent $\mathrm{SnCl}_{2} \cdot 2 \mathrm{H}_{2} \mathrm{O}(11.8 \mathrm{~g}, 10$ equiv.) and concentrated $\mathrm{HCl}(200 \mathrm{~mL})$ was added slowly to the mixture. The resulting green solution was stirred for 2 days at RT. After completion of the reaction (monitored by MALDI), it was quenched by aqueous $\mathrm{KOH}$ solution at $0{ }^{\circ} \mathrm{C}$ under ice. The resulting violet solution was washed several times with water and $\mathrm{CHCl}_{3}$. The organic layers were collected and dried over $\mathrm{MgSO}_{4}$. Yield: $2.95 \mathrm{~g}(80 \%)$.

Steric decompression of two atropisomers. In a $1 \mathrm{~L}$ two necks round bottom flask equipped with a stir bar and a condenser, $200 \mathrm{~g}$ of silica $(60 \mu \mathrm{m})$ were added to toluene $(400 \mathrm{~mL})$. The reaction mixture was heated to $80^{\circ} \mathrm{C}$ and degassed with argon during $45 \mathrm{~min}$. Then $2.9 \mathrm{~g}$ of the $\alpha \beta$ and $\alpha \alpha$ atropisomers of the bis-2-aminophenylporphyrin obtained previously were dissolved in toluene and added to the silica gel mixture in toluene. After evaporation of the solvent, the compound was dissolved in minimum amount of $\mathrm{CH}_{2} \mathrm{Cl}_{2}$ and purified by column chromatography. The two atropisomers were separated on a silica gel chromatography eluted with $\mathrm{CH}_{2} \mathrm{Cl}_{2} / \mathrm{MeOH}(\alpha \beta 0.2 \%, \alpha \alpha 0.5 \%)$. Yield: $5 \alpha \alpha$ $(1.9 \mathrm{~g}, 66 \%), \alpha \beta(0.9 \mathrm{~g}, 34 \%)$. It is worth to note that the atropisomer $\alpha \alpha \mathbf{5}$ remains contaminated with by-products resulting from scrambling reactions not separable by silica gel flash chromatography and has not been fully characterized.

a-5,15-bis-(2-[\{3-chloromethyl\}benzoylamido]-phenyl)-10,20-bis-(4-methoxyphenyl)-porphyrin 6. A $500 \mathrm{~mL}$ two neck round bottom flask equipped with a stirrer and cooled in an ice bath was charged with compound 5 (0.99 mmol, $700 \mathrm{mg}$ ), dry $\mathrm{CH}_{2} \mathrm{Cl}_{2}$ (300 mL) and $\mathrm{NEt}_{3}(350 \mu \mathrm{L}, 2.5$ equiv.). 3-(chloromethyl)benzoyl chloride (420 $\mu \mathrm{L}, 3$ equiv.) was then added dropwise under argon atmosphere. The reaction mixture was allowed to stir for three hours. Then the reaction was quenched by water and the organic layer was separated. The solvent was removed under vacuum. The resulting solid was dissolved in $\mathrm{CH}_{2} \mathrm{Cl}_{2}$ and directly loaded on a silica gel chromatography column. The expected compound eluted with $0.2 \% \mathrm{CH}_{2} \mathrm{Cl}_{2} / \mathrm{MeOH}$, was obtained in $90 \%$ yield $(902 \mathrm{mg}) .{ }^{1} \mathrm{H} \mathrm{NMR}\left(\mathrm{CDCl}_{3}, 298 \mathrm{~K}, 500.13\right.$ $\mathrm{MHz}): \delta 8.93(4 \mathrm{H}, \mathrm{d}, J=4.81 \mathrm{~Hz}, \beta \mathrm{pyr}), 8.87(4 \mathrm{H}, \mathrm{d}, \beta \mathrm{pyr}), 8.93\left(2 \mathrm{H}, \mathrm{d}, J=8.06 \mathrm{~Hz}, \operatorname{aro}_{2}\right), 8.13(2 \mathrm{H}, \mathrm{d}, J=7.49 \mathrm{~Hz}$, $\left.\operatorname{aro}_{5}\right), 8.11\left(2 \mathrm{H}, \mathrm{d}, J=7.60 \mathrm{~Hz}, \operatorname{aro}_{9}\right), 8.02\left(2 \mathrm{H}, \mathrm{d}, J=7.60 \mathrm{~Hz}, \operatorname{aro}_{9}\right), 7.91\left(2 \mathrm{H}, \mathrm{t},{ }^{3} J=8.06 \mathrm{~Hz}, \operatorname{aro}_{3^{\prime}}\right), 7.63(2 \mathrm{H}, \mathrm{s}$, 
NHCO), $7.59\left(2 \mathrm{H}, \mathrm{t}, J=7.49 \mathrm{~Hz}, \operatorname{aro}_{4}{ }^{\prime}\right), 7.28\left(4 \mathrm{H}, \mathrm{bs}, \operatorname{aro}_{8}, \operatorname{aro}_{8^{\prime}}\right), 6.73\left(2 \mathrm{H}, \mathrm{d}, J=7.68 \mathrm{~Hz}, \operatorname{aro}_{4}\right), 6.55(2 \mathrm{H}, \mathrm{d}, J=7.90$ $\left.\mathrm{Hz}, \operatorname{aro}_{6}\right), 6.49\left(2 \mathrm{H}, \mathrm{t}, J=7.68, \operatorname{aro}_{5}\right), 6.33\left(2 \mathrm{H}, \mathrm{s}, \operatorname{aro}_{2}\right), 4.09(6 \mathrm{H}, \mathrm{s}, \mathrm{OMe}), 3.30\left(4 \mathrm{H}, \mathrm{s}, \mathrm{CH}_{2 \mathrm{bz}}\right),-2.61\left(2 \mathrm{H}, \mathrm{s}, \mathrm{NH}_{\mathrm{int}}\right)$. ${ }^{13} \mathrm{C} \mathrm{NMR}\left(\mathrm{CDCl}_{3}, 298 \mathrm{~K}, 500.13 \mathrm{MHz}\right): \delta 164.7,159.7,138.7,137.1,135.7,135.6,134.9,134.7,133.6,131.7,130.8$, 129.9, 128.4, 126.2, 126.1, 123.2, 120.9, 120.7, 113.7, 112.5, 112.4, 55.6, 44.3. ESI-HRMS: calcd m/z = 1009.3030 $[\mathrm{M}+\mathrm{H}]^{+}$for $\mathrm{C}_{62} \mathrm{H}_{47} \mathrm{~N}_{6} \mathrm{O}_{4}{ }^{35} \mathrm{Cl}_{2}$, found 1009.3031, calcd $\mathrm{m} / \mathrm{z}=973.3263[\mathrm{M}-\mathrm{HCl}+\mathrm{H}]^{+}$for $\mathrm{C}_{62} \mathrm{H}_{46} \mathrm{~N}_{6} \mathrm{O}_{4}{ }^{35} \mathrm{Cl}$, found 973.3268. UV-vis (DMF): $\lambda / \mathrm{nm}\left(10^{-3} \varepsilon, \mathrm{dm}^{3} \mathrm{~mol}^{-1} \mathrm{~cm}^{-1}\right): 426$ (364), 521 (14), 558 (8), 599 (4), 652 (3.4).

\section{$\alpha-5,15-b i s-(\{2,2-(3,3-[2,2-($ diethoxycarbonyl)propane-1,3-diyl]-dibenzoyl-amido]-diphenyl)-10,20-bis-(4-}

methoxyphenyl)-porphyrin 7. Sodium metal (182 mg, 10 equiv.) was added to the absolute alcohol (20 mL) in a small round bottom flask and stirred for few minutes until the complete consumption of Na. Diethyl malonate $(1.2 \mathrm{~mL}, 10$ equiv.) was added to this solution at room temperature and stirred for half an hour. The resulting mixture was added to a solution of porphyrin 6 (0.79 mol, $800 \mathrm{mg}, 1$ equiv.) in $\mathrm{CH}_{2} \mathrm{Cl}_{2}(600 \mathrm{~mL})$ and the solution was turned immediately from violet to green. After $2 \mathrm{~h}$ of stirring the reaction was quenched by $\mathrm{H}_{2} \mathrm{O}$, the organic layer was separated and removed under vacuum. The desired product was purified on a silica gel chromatography column eluted with $0.3 \%$ $\mathrm{CH}_{2} \mathrm{Cl}_{2} / \mathrm{MeOH}$. The expected compound was obtained in $80 \%$ yield $(702 \mathrm{mg}) .{ }^{1} \mathrm{H} \mathrm{NMR}\left(\mathrm{CDCl}_{3}, 298 \mathrm{~K}, 500 \mathrm{MHz}\right): \delta$ $9.15\left(2 \mathrm{H}, \mathrm{d}, J=8.39 \mathrm{~Hz}, \operatorname{aro}_{2}\right), 8.93(4 \mathrm{H}, \mathrm{d}, J=4.58 \mathrm{~Hz}, \beta \mathrm{pyr}), 8.86$ (4H, d, $\left.J=4.58 \mathrm{~Hz}, \beta \mathrm{pyr}\right), 8.22$ (2H, s, NHCO), $8.19\left(2 \mathrm{H}, \mathrm{bs}, \operatorname{aro}_{9}\right), 8.01\left(2 \mathrm{H}, \mathrm{d}, 2 \mathrm{H}_{1}, J=7.54 \mathrm{~Hz}, \operatorname{aro}_{5}\right), 7.98\left(2 \mathrm{H}, \mathrm{bs}, \operatorname{aro}_{9}\right), 7.91\left(2 \mathrm{H}, \mathrm{t},{ }^{3} J=7.70 \mathrm{~Hz}, \operatorname{aro}_{3^{\prime}}\right), 7.70(2 \mathrm{H}$, $\left.\mathrm{d}, 2 \mathrm{H}_{\mathrm{h}}, J=7.98 \mathrm{~Hz}, \operatorname{aro}_{6}\right), 7.55\left(2 \mathrm{H}, \mathrm{t},{ }^{3} \mathrm{~J}=7.70 \mathrm{~Hz}, \operatorname{aro}_{4}\right), 7.31\left(4 \mathrm{H}, \mathrm{bs}, \operatorname{aro}_{8}, \operatorname{aro}_{8}\right), 6.98\left(2 \mathrm{H}, \mathrm{t},{ }^{3} J=7.90 \mathrm{~Hz}, \operatorname{aro}_{5}\right)$, $6.74\left(2 \mathrm{H}, \mathrm{d}, J=7.90 \mathrm{~Hz}, \operatorname{aro}_{4}\right), 4.99\left(2 \mathrm{H}, \mathrm{s}, \operatorname{aro}_{2}\right), 4.08\left(6 \mathrm{H}, \mathrm{s}, \mathrm{OCH}_{3}\right), 1.70\left(4 \mathrm{H}, \mathrm{s}, \mathrm{CH}_{2} \mathrm{bz}\right), 1.23\left(4 \mathrm{H}, \mathrm{bs}, \mathrm{CH}_{2}\right.$ ester $),-$ $0.55\left(6 \mathrm{H}, \mathrm{t}, J=6.58 \mathrm{~Hz}, \mathrm{CH}_{3}\right.$ ester $),-2.40\left(2 \mathrm{H}, \mathrm{s}, \mathrm{NH}_{\mathrm{int}}\right) .{ }^{13} \mathrm{C} \mathrm{NMR}\left(\mathrm{CDCl}_{3}, 298 \mathrm{~K}, 500 \mathrm{MHz}\right): \delta 167.5,164.4,159.6$, 138.8, 135.9, 135.2, 134.9, 133.8, 133.7, 132.4, 131.2, 129.9, 128.2, 127.4, 125.9, 122.8, 120.7, 119.7, 113.7, 112.5, 59.9, 58.8, 55.5, 42.5, 11.9. ESI-HRMS: calcd m/z = 1097.4232 [M+H] ${ }^{+}$for $\mathrm{C}_{69} \mathrm{H}_{57} \mathrm{~N}_{6} \mathrm{O}_{8}$, found 1097.4234, calcd m/z = 1119.4051 [M+Na] $]^{+}$for $\mathrm{C}_{69} \mathrm{H}_{56} \mathrm{~N}_{6} \mathrm{O}_{8} \mathrm{Na}$, found 1119.4047. UV-vis (DMF): $\lambda / \mathrm{nm}\left(10^{-3} \varepsilon, \mathrm{dm}^{3} \mathrm{~mol}^{-1} \mathrm{~cm}^{-1}\right): 425(380), 520$ (15.8), 558 (8.2), $596(4.4), 653(3.4)$.

$\alpha-5,15-b i s-(\{\{2,2-(3,3-[2,2-($ dicarboxylic

acid)propane-1,3-diyl]-dibenzoyl-amido]-diphenyl)-10,20-bis-(4hydroxyphenyl)-porphyrin 2. Boron tribromide (2.5 mL, 50 equiv.) was added to compound 7 (0.54 mmol, $600 \mathrm{mg})$ was dissolved in DCM $(100 \mathrm{~mL})$. After $12 \mathrm{~h}$ of stirring at RT, the reaction was completed. The mixture was quenched by water. The precipitated compound was filtered and the green solid was washed with water at $\mathrm{pH}=7$. The product was purified by silica gel chromatography column and eluted with $\mathrm{CHCl}_{3} / \mathrm{MeOH} / \mathrm{AcOH}(90 / 9 / 1)$. Yield: $80 \%(440 \mathrm{mg})$. ${ }^{1} \mathrm{H}$ NMR (DMSO-d 6 , 298 K, $500.13 \mathrm{MHz}$ ): $\delta 9.92$ (2H, s, OH), 8.84 (4H, d, J = $4.55 \mathrm{~Hz}, \beta \mathrm{pyr}), 8.77(4 \mathrm{H}, \mathrm{d}, J=4.55 \mathrm{~Hz}$,

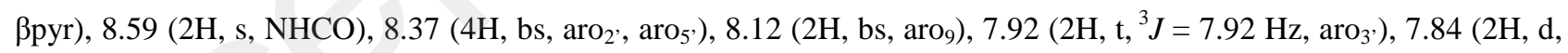
$\left.J=6.25 \mathrm{~Hz}, \operatorname{aro}_{9}\right), 7.75\left(2 \mathrm{H}, \mathrm{t},{ }^{3} J=7.60 \mathrm{~Hz}, \operatorname{aro}_{4}\right), 7.24\left(2 \mathrm{H}, \mathrm{d}, J=8.04 \mathrm{~Hz}, \operatorname{aro}_{6}\right), 7.16\left(4 \mathrm{H}, \mathrm{bs}, \operatorname{aro}_{8}, \operatorname{aro}_{8}\right), 6.90(2 \mathrm{H}$, $\left.\mathrm{t},{ }^{3} J=7.49 \mathrm{~Hz}, \operatorname{aro}_{5}\right), 6.72\left(2 \mathrm{H}, \mathrm{d}, J=7.77 \mathrm{~Hz}, \operatorname{aro}_{4}\right), 4.57\left(2 \mathrm{H}, \mathrm{s}, \operatorname{aro}_{2}\right), 1.19\left(4 \mathrm{H}, \mathrm{s}, \mathrm{CH}_{2} \mathrm{bz}\right),-2.70\left(2 \mathrm{H}, \mathrm{bs}, \mathrm{NH}_{\mathrm{int}}\right) .{ }^{13} \mathrm{C}$ NMR (DMSO-d ${ }_{6}, 298$ K, 500 MHz): $\delta 171.5,165.7,157.8,139.2,136.2,135.9,135.7,135.3,134.9,134.8,132.1,132$, 129.7, 128.1, 126.8, 126.4, 124.6, 124.3, 120.7, 115.3, 114.3, 59.3, 40.49. ESI-HRMS: calcd m/z = 1013.3293 [M+H] ${ }^{+}$ for $\mathrm{C}_{63} \mathrm{H}_{45} \mathrm{~N}_{6} \mathrm{O}_{8}$, found 1013.3288, calcd $\mathrm{m} / \mathrm{z}=1035.3112[\mathrm{M}-\mathrm{H}+\mathrm{Na}]^{+}$for $\mathrm{C}_{63} \mathrm{H}_{43} \mathrm{~N}_{6} \mathrm{NaO}_{8}$, found 1035.3102. UV-vis (DMF): $\lambda / \mathrm{nm}\left(10^{-3} \varepsilon, \mathrm{dm}^{3} \mathrm{~mol}^{-1} \mathrm{~cm}^{-1}\right): 428$ (344), 522 (19), 560 (12), 599 (7.6), 655 (6).

Iron insertion. A free-base solution of porphyrin 2 in THF in the presence of an excess of iron bromide and 2,6-lutidine was heated at reflux overnight inside a glove box. During this process, the decarboxylation reaction leading to both $\mathbf{1 F e}$ and $2 \mathrm{Fe}$ was observed and the two complexes were obtained in roughly equal proportions as indicated by TLC analysis. The resulting mixture was taken out of the glove box, washed with $\mathrm{HCl}(1 \mathrm{M})$, and dried. There were easily separated by 
silica gel chromatography using a gradient of $\mathrm{MeOH}$ in $\mathrm{CHCl}_{3}$ (from $0.2 \%$ to $2.2 \%$ ) and identified by MALDI-TOF mass spectrometry (1Fe: 41\%, $\left.[\mathrm{M}+\mathrm{H}]^{+} 1022.30 ; \mathbf{2 F e}: 37 \%,[\mathrm{M}+\mathrm{H}]^{+} 1066.41\right)$.

MWNT. MWNTs (60 mg) were sonicated in nitric acid (35 vol \%) (150 mL) with a sonic bath (Fisherbrand, 37kHz, power $100 \%$ for $10 \mathrm{~min}$ and then $40 \%$ for $30 \mathrm{~min}$ ) and then heated at $100^{\circ} \mathrm{C}$ for $5 \mathrm{~h}$. The suspension was then cooled and vacuum filtered through a $0.2 \mu \mathrm{m}$ PTFE membrane and washed with water. The nanotubes were redispersed in $\mathrm{NaOH} 2 \mathrm{M}(100 \mathrm{~mL})$ using the sonic bath $(100 \%$ for $10 \mathrm{~min})$ and then filtered through a PTFE membrane and washed with deionized water, and then $\mathrm{HCl} 1 \mathrm{M}$ followed by deionized water until the filtrate was neutral.

Electrochemical experiments. Sample preparation. For the preparation of the sample containing nanotubes (MWNT1Fe, MWNT-2Fe), a mixture of purified MWNT $(9 \mathrm{mg})$ and porphyrin 1Fe $(9 \mathrm{mg})$ or porphyrin $2 \mathrm{Fe}(9 \mathrm{mg})$ in dry THF $(10 \mathrm{ml})$ was homogenized using a sonic bath (Fisherbrand, 37kHz, power 100\%) for 15 min. The THF was gently evaporated with a steam of $\mathrm{N}_{2}$ and the mixtures were dried under vacuum. $3 \mathrm{mg}$ of mixture were dispersed in $750 \mu 1$ of ethanol and $75 \mu \mathrm{l}$ of Nafion solution (5\% in alcohol). The mixtures were homogenized using a sonic bath until they formed homogenous inks. For the MWNT ink, the same procedure was followed but without adding porphyrins. For the reference 1Fe and $\mathbf{2 F e}$ inks, $3 \mathrm{mg}$ of porphyrins were directly dispersed in $750 \mu \mathrm{l}$ of ethanol and $75 \mu 1$ of Nafion solution ( $5 \%$ in alcohol)

Electrode preparation. Before each measurement, the glassy carbon (GC) disk $\left(5 \mathrm{~mm}, 0.196 \mathrm{~cm}^{2}\right)$ used as rotating electrode was polished with aqueous dispersions of synthetic diamonds $(1 \mu \mathrm{m})$, then rinsed and sonicated with water. 5 $\mu \mathrm{l}$ of the catalyst inks were deposited by drop-casting onto the GC disk, then dried in air. For pH 6, a new ink was deposited onto the GC disk for each rotation step.

Electrochemical measurements. The instrument used was a VSP bipotentiostat (Bio-Logic SAS). The electrochemical tests were carried out in $0.5 \mathrm{M} \mathrm{H}_{2} \mathrm{SO}_{4}$ solution in a three electrode glass cell, thermostated at $25^{\circ} \mathrm{C}$. A " $\mathrm{CE}$ to Ground" connection with a saturated $\mathrm{KCl} \mathrm{Ag} / \mathrm{AgCl}$ electrode as reference and a graphite plate as counter electrode was used. As working electrode, a Pine rotating ring disk electrode (RRDE) with catalyst-loaded GC disk $\left(0.196 \mathrm{~cm}^{2}\right)$ and Pt ring $\left(0.110 \mathrm{~cm}^{2}\right)$ was controlled by a speed control unit from Princeton Applied Research Model 636 Electrode Rotator. The voltammograms were recorded at $5 \mathrm{mV} . \mathrm{s}^{-1}$ in stationary conditions (with various rotating rates: 0, 400, 800, 1200, 1600, and $2000 \mathrm{rpm}$ ) in $\mathrm{O}_{2}$-saturated solutions. An average current was calculated from the forward and backward scans. All potentials reported in this paper refer to that of the $\mathrm{Ag} / \mathrm{AgCl}$ electrode $\mathrm{H}_{2} \mathrm{O}_{2}$ production was monitored in the RRDE configuration at $400 \mathrm{rpm}$ with a $\mathrm{CV}$ at the $\mathrm{GC}$ disk $\left(5 \mathrm{mV} . \mathrm{s}^{-1}\right)$. The collection coefficient of the RRDE (0.20) was measured using the one-electron $\mathrm{Fe}(\mathrm{CN})_{6}{ }^{3-} / \mathrm{Fe}(\mathrm{CN})_{6}{ }^{4-}$ redox couple, according to the manufacturer's instructions.

\section{X-ray crystallographic studies.}

CCDC 1916858, $\mathrm{C}_{62} \mathrm{H}_{41} \mathrm{FeN}_{6} \mathrm{O}_{6}, M=1021.86$. D8 VENTURE Bruker AXS diffractometer equipped with a (CMOS)

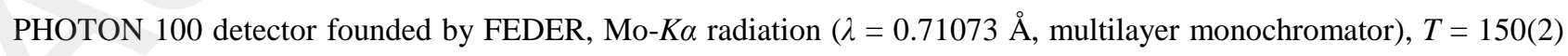
K; triclinic $P$-1 (I.T.\#2), $a=14.499(2), b=14.729(2), c=17.848(3) \AA, \alpha=90.838(5), \beta=109.567(6), \gamma=117.362(5)$ ${ }^{\circ}, V=3124.0(8) \AA^{3} \cdot Z=2, d=1.086 \mathrm{~g} \cdot \mathrm{cm}^{-3}, \mu=0.291 \mathrm{~mm}^{-1}$. The structure was solved by dual-space algorithm using the SHELXT program [26], and then refined with full-matrix least-squares methods based on $F^{2}$ (SHELXL) [27]. The contribution of the disordered solvents to the calculated structure factors was estimated following the BYPASS algorithm [28], implemented as the SQUEEZE option in PLATON [29]. A new data set, free of solvent contribution, was then used in the final refinement. All non-hydrogen atoms were refined with anisotropic atomic displacement parameters. $\mathrm{H}$ atoms were finally included in their calculated positions and treated as riding on their parent atom with constrained thermal 
parameters. A final refinement on $F^{2}$ with 13966 unique intensities and 672 parameters converged at $\omega R\left(F^{2}\right)=0.2340$ $(R(F)=0.0888)$ for 9825 observed reflections with $I>2 \sigma(I)$.

Supporting Information composed of the CIF file, detailed spectroscopic data and detailed electrochemical measurements.

Crystallographic data (excluding structure factors) for the structures reported in this paper have been deposited at the Cambridge Crystallographic Data Center under deposition number 1916858. Copies can be obtained on request, free-ofcharge, at www.ccdc.cam.ac.uk/conts/retrieving.html or from the Cambridge Crystallographic Data Centre, 12 Union Road, Cambridge CB2 1EZ, UK (fax: +44 1223-336-033 or email: deposit@ccdc.cam.ac.uk).

\section{Acknowledgements}

Région Bretagne as well as well as CNRS are deeply acknowledged for their significant support to our research team. This work was also supported by the JST-ANR program TMOL "Molecular Technology" project MECANO (ANR-14JTIC-0002-01) and project MAGMA (ANR-16-CE29-0027-01). 


\section{Oxygen Reduction Reaction Catalyzed by Overhanging Carboxylic Acid Strapped Iron Porphyrins Adsorbed on Carbon Nanotubes}

Bernard Boitrel," Morgane Bouget, Pradip K. Das, Stéphane Le Gac, Thierry Roisnel, Manel Hanana, Hélène Arcostanzo, Renaud Cornut, Bruno Jousselme, and Stéphane Campidelli*

Hybrid catalysts for the oxygen reduction reaction (ORR) composed of multi-wall carbon nanotubes (MWNTs) coated with iron strapped porphyrins bearing one or two overhung carboxylic acid(s) show better catalytic activity than both components do separately.

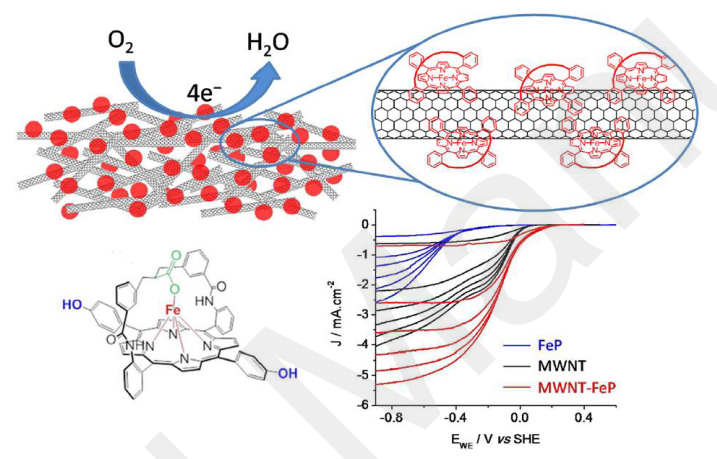




\section{REFERENCES}

1. Momenteau M and Reed CA. Chem. Rev. 1994; 94: 659-698.

2. Lemon CM, Dogutan DK and Nocera DG. In Handbook of Porphyrin Science, Vol. 21, Catalysis, Kadish KM, Smith KM, Guilard R. (Eds.) Word Scientific: Singapore, 2012; pp 1-143.

3. Bezerra CWB, Zhang L, Lee K, Liu H, Marques ALB, Marques EP, Wang H, Zhang J. Electrochem. Acta 2008; 53: 4937-4951.

4. Kim E, Chufan EE, Kamaraj K and Karlin KD. Chem. Rev. 2004; 104: 1077-1133.

5. Collman JP, Devaraj NK, Decréau RA, Yang Y, Yan Y-L, Ebina W, Eberspacher TA and Chidsey CED. Science 2007; 315: 1565-1568.

6. Ricard D, Andrioletti B, L'Her M and Boitrel B. Chem. Commun. 1999: 1523-1524.

7. Ricard D, L'Her M, Richard P and Boitrel B. Chem. Eur. J. 2001; 7: 3291-3297.

8. Ricard D, Didier A, L'Her M and Boitrel B. C. R. Chim. 2002; 5: 33-36.

9. Ricard D, Didier A, L'Her M and Boitrel B. ChemBioChem 2001; 2: 144-148.

10. Rosenthal J and Nocera DG. Acc. Chem. Res. 2007; 40: 543-553.

11. Rosenthal J and Nocera DG. Prog. Inorg. Chem. 2007; 55: 483-544.

12. Carver CT, Matson BD and Mayer JM. J. Am. Chem. Soc. 2012; 134: 5444-5447.

13. Morozan A, Campidelli S, Filoramo A, Jousselme B, Palacin S.Carbon 2011; 49: 4839-4847.

14. Rigsby ML, Wasylenko DJ, Pegis ML and Mayer JM. J. Am. Chem. Soc. 2015; 137: 4296-4299.

15. Hanana M, Arcostanzo H, Das PK, Bouget M, Le Gac S, Okuno H, Cornut R, Jousselme B, Dorcet V, Boitrel B and Campidelli S. New. J. Chem. 2018; 42: 19749-19754.

16. Balieu S, Halime Z, Lachkar M and Boitrel B. J. Porphyrins Phthalocyanines 2008; 12: 1223-1231.

17. Le Gac S, Najjari B, Dorcet V, Roisnel T, Fusaro L, Luhmer M, Furet E, Halet J-F and Boitrel B. Chem. Eur. J. 2013; 19: 11021-11038.

18. Kruusenberg I, Alexeyeva N, Tammeveski K. Carbon 2009; 47: 651-658.

19. Morozan A, Jégou P, Pinault M, Campidelli S, Jousselme B, Palacin S. ChemSusChem 2012; 5: 647-651.

20. van Veen JAR, Colijn HA. Ber. Bunsenges. Phys. Chem. 1981; 85: 700-704.

21. Choi CH, Baldizzone C, Polymeros G, Pizzutilo E, Kasian O, Schuppert AK, Sahraie NR, Sougrati MT, Mayrhofer KJJ, Jaouen F. ACS Catal. 2016; 6: 3136-3146.

22. Meier H, Tschirwitz U, Zimmerhackl E, Albrecht W, Zeitler G. J. Phys. Chem. 1977; 81: 712-718.

23. Baraton S, Coutanceau C, Roux C, Hahn F, Léger JM. O J. Electroanal. Chem. 2005; 577: 223-234.

24. Li W, Yu A, Higging DC, Llanos BG, Chen ZB. J. Am. Chem. Soc. 2010; 132: 17056-17058.

25. Zhou R, Zheng Y, Jaroniec M and Qiao S-Z. ACS Catal. 2016; 6: 4720-4728.

26. Sheldrick GM. Acta Cryst. 2015; A71: 3-8.

27. Sheldrick GM. Acta Cryst. 2015; C71: 3-8.

28. Sluis Pvd and Spek AL. Acta Cryst. 1990; A46: 194-201.

29. Spek AL. J. Appl. Cryst. 2003; 36: 7-13 